\title{
Urokinase of plasminogen activator (UPA) in peritoneal fluid in patients with peritonitis
}

\author{
Urokinazowy aktywator plazminogenu (UPA) w płynie otrzewnowym u chorych \\ na zapalenie otrzewnej
}

\author{
Stanisław Czeszak', Anna Moskwa-Ziętek², Zbigniew Ziętek,4凶 \\ ${ }^{1}$ Samodzielny Publiczny Zakład Opieki Zdrowotnej Ministerstwa Spraw Wewnętrznych i Administracji w Szczecinie, ul. Jagiellońska 44, 70-382 Szczecin \\ Department of General Surgery of Ministry Interior Affairs and Administration \\ ${ }^{2}$ Samodzielny Publiczny Wojewódzki Szpital Zespolony w Szczecinie, Oddział Reumatologii, ul. Arkońska 4, 71-455 Szczecin \\ Independent Public Provincial Hospital, Department of Rheumatology \\ ${ }^{3}$ Pomorski Uniwersytet Medyczny w Szczecinie, Klinika Chirurgii i Transplantologii, al. Powstańców Wlkp. 72, 70-110 Szczecin \\ Pomeranian Medical University in Szczecin, Clinic of General Surgery and Transplantology \\ ${ }^{4}$ Pomorski Uniwersytet Medyczny w Szczecinie, Katedra i Zakład Anatomii Prawidłowej i Klinicznej, al. Powstańców Wlkp. 72, 70-110 Szczecin \\ Pomeranian Medical University in Szczecin, Department of Normal and Clinical Anatomy \\ zzietek@poczta.onet.pl
}

\begin{abstract}
Introduction: There is a perturbation of the natural intra-peritoneal environment in peritonitis. The significant issue for treatment outcomes of peritonitis is connected with intra-peritoneal fibrinolysis.

The aim of the study was to determine the concentration of urokinase plasminogen activator (UPA) in peritoneal fluid in patients operated for peritonitis.

Materials and methods: The study group consisted of 65 patients ( 28 women and $37 \mathrm{men}$ ) at a mean age $45 \pm 18$ years diagnosed with peritonitis. The causes of peritoneal inflammation were acute appendicitis, acute cholecystitis, acute pancreatitis and obstruction of the gastrointestinal tract. The exclusion criterion for the study was cancer, any thrombolytic or antithrombotic
\end{abstract}

therapy. The peritoneal fluid obtained during the surgical procedure was collected for study, in which the concentration of uPA was determined.

Results: In the peritoneal fluid of operated patients, uPA was found. The concentration was significantly higher than that determined in their blood plasma $(p<0.0001)$.

Conclusions: The presence of uPA in peritoneal fluid, the concentration of which was significantly higher than in the blood plasma, indicates that during peritonitis there are some conditions for the activation of intra-peritoneal fibrinolysis. However, further investigations are required, including other components of the fibrinolysis cascade.

Keywords: peritonitis; urokinase plasminogen activator; fibrinolysis; peritoneal fluid.

\begin{abstract}
ABSTRAKT
Wstęp: W zapaleniu otrzewnej dochodzi do zaburzenia naturalnego środowiska wewnątrzotrzewnowego. Istotna kwestia dotycząca wyników leczenia zapalenia otrzewnej związana jest z fibrynolizą dootrzewnową.

Celem pracy było określenie stężenia urokinazowego aktywatora plazminogenu (uPA) w płynie otrzewnowym u chorych operowanych z powodu zapalenia otrzewnej.

Materiały i metody: Grupę badaną stanowiło 65 chorych $(28$ kobiet i 37 mężczyzn) w średniej wieku $45 \pm 18$ lat z rozpoznanym zapaleniem otrzewnej. Jego przyczyną było ostre zapalenie wyrostka robaczkowego, ostre zapalenie pęcherzyka żółciowego, ostre zapalenie trzustki oraz niedrożność przewodu pokarmowego. Kryterium wykluczającym była choroba nowotworowa
\end{abstract}

oraz jakakolwiek terapia trombolityczna lub przeciwzakrzepowa. Do badania pobierano uzyskany podczas zabiegu operacyjnego płyn otrzewnowy, w którym określano stężenie uPA.

Wyniki: W płynie otrzewnowym u operowanych chorych wykazano obecność uPA, którego stężenie było znacznie wyższe niż stężenie oznaczone w osoczu krwi badanych $(\mathrm{p}<0,0001)$.

Wnioski: Obecność w płynie otrzewnowym uPA, którego stężenie było znacznie wyższe niż w osoczu krwi, wskazuje, że podczas zapalenia otrzewnej istnieją pewne warunki do aktywacji fibrynolizy wewnątrzotrzewnowej. Konieczne są jednak dalsze badania, obejmujące także inne składniki kaskady fibrynolizy. Słowa kluczowe: zapalenie otrzewnej; urokinazowy aktywator plazminogenu; fibrynoliza; płyn otrzewnowy.

\section{INTRODUCTION}

Current knowledge of the peritoneum is a result of "the global engagement of many centres", focused on the complex interactions of molecules, cells, tissues, and organs that may be more appropriate for comprehension of the many pathomechanisms of the peritoneum [1]. The peritoneum is composed of 2 mesothelial layers - visceral and parietal. These 2 layers and the liquid-filled space in between compose the peritoneal cavity [2,3]. The peritoneum is generally described as a protective barrier that covers the abdominal organs, but in fact it is a much more complex structure with a great variety of functions [4]. One is 
tissue repair and scarring [5]. The mesothelial cells have demonstrated the ability to participate in fibrinolytic, procoagulant and fibrinogenic activity $[6,7,8]$. The fibrinolytic system includes a broad spectrum of proteolytic enzymes with physiological and pathophysiological functions in several processes, such as haemostatic balance, tissue remodeling, tumor invasion, angiogenesis and reproduction. The main enzyme of the plasminogen activator system is plasmin, which is responsible for the degradation of fibrin into soluble degradation products. The activation of plasminogen into plasmin is mediated by 2 types of activators, urokinase-type plasminogen activator (uPA) and tissue-type plasminogen activator (t-PA) [9]. In clinical practice, surgeons and all type of physicians are in constant look out for signs of peritoneal irritation. A large amount of everyday surgeries occur in the peritoneal cavity [10]. One of the serious complications after abdominal surgery is early or late postoperative ileus. Peritoneal fibrinolysis is responsible for healing of the peritoneal cavity, but it can also play a role in the formation of postoperative adhesions. In fact, postoperative adhesion formation could be regulated by peritoneal fibrinolysis, but the virtual responses of fibrinolysis to surgery is unknown yet. A reduced peritoneal fibrinolytic capacity after surgery is pointed out by many authors. Many of them regard it as the main cause of postoperative adhesions $[11,12,13]$. It is confirmed by other studies which have shown that peritoneal fibrinolytic activity could be depressed not only by surgery but also by inflammatory process of the peritoneum [14]. In contrast to the concept of reduced peritoneal fibrinolysis in peritonitis, another group of authors showed that intraperitoneal fibrinolysis not only did not diminish, but even significantly increased. The authors observed increased local production of plasminogen activators in peritoneal tissue [14].

Based on the above, it seems that plasminogen activator system may be involved in the peritonitis process, where local extracellular proteolysis plays a crucial role. It is well established that in extravascular proteolysis based on plasmin, uPA is very important [15].

The aim of this study was to determine the concentration of UPA in peritoneal fluid in patients with peritonitis.

\section{MATERIALS AND METHODS}

A group of 65 patients with peritonitis, of which 28 were women and 37 men aged $18-79$ years (mean age $45 \pm 18$ years) were qualified for the study. Detailed characteristics of patients including the cause of peritonitis are given in Table 1.

TABLE 1. List of causes of peritonitis and type of surgery

\begin{tabular}{llc}
\multicolumn{1}{c}{$\begin{array}{c}\text { The cause } \\
\text { of peritonitis }\end{array}$} & \multicolumn{1}{c}{$\begin{array}{c}\text { The type } \\
\text { of surgery }\end{array}$} & $\begin{array}{c}\text { Number } \\
\text { of patients }(\%)\end{array}$ \\
\hline Acute appendicitis & appendectomy & $27(41)$ \\
\hline Acute cholecystitis & cholecystectomy & $10(15)$ \\
\hline Ileus & explorative laparotomy & $16(25)$ \\
\hline Acute pancreatitis & laparotomy/necrectomy & $12(19)$ \\
\hline
\end{tabular}

The exclusion criteria were the patient's objection or any thromboembolic therapy. Diagnosis of peritonitis was based on common clinical symptoms that were confirmed in imaging and laboratory tests. Both in blood plasma and peritoneal fluid the concentration of urokinase antigen of plasminogen activator (uPA:Ag) was determined. Peritoneal fluid obtained from patients during percutaneous surgery or percutaneous puncture was assigned to the study. An average of approximately $20.0 \mathrm{~mL}$ of fluid was collected, about $10 \mathrm{~mL}$ of which was poured into a plastic tube containing $3.2 \%$ sodium citrate at a ratio of 10:1, and the remaining fluid was used for other biochemical tests, such as total protein concentration, for example. Due to technical and ethical reasons, it was not possible to determine the concentration of uPA:Ag in the peritoneal fluid of healthy volunteers, so that in each patient qualified for the study, blood was taken, which was the reference value for peritoneal fluid. Blood was collected from patients before and after surgery. The uPA:Ag values in the blood after the surgery were reference values for the fluid. In order to obtain the maximum objective comparison of peritoneal fluid with blood plasma, the total protein concentration was determined for each of these fluids, and the next concentration of uPA:Ag in the blood plasma and peritoneal fluid was calculated per gram of protein contained in both. For the determination of uPA:Ag, the ELISA method was applied on commercial kits. The kit for determination of UPA:Ag is an immunoenzymatic test for the quantification of human uPA in plasma, tissue extracts, cell cultures, as well as body fluids such as peritoneal fluid. The test technique is based on the ELISA sandwich test. Its essence is the comparison of specific and nonspecific reactions of the formation of uPA-mediated complexes. The producer does not provide a laboratory norm which should be elaborated by each laboratory. The range of normal values was determined in the blood of 25 healthy volunteers ( 10 women and 15 men at a median age of $50 \pm 18$ years). Statistical analysis of the uPA concentrations was made on the basis of routine tests. The evaluation of the normality distribution of uPA values in both the blood plasma and peritoneal fluid was made on the basis of a Shapiro-Wilk U test. In the case of a normal distribution, statistical analysis included mean $(\mathrm{X})$ and standard deviation (SD) values, otherwise the median value and I-III quartile. For a normal distribution, statistical significance was assessed according to a Student's t test; otherwise, a Mann-Whitney $\mathrm{U}$ test was applied. For the correlation of uPA between blood plasma and peritoneal fluid, a Spearman rank factor / nontypical distribution / Pearson coefficient / normal distribution was applied. In all calculations, the statistical significance value was $\mathrm{p}<0.05$. The research project was approved by the Local Ethics Commission/KB 130/2001/.

\section{RESULTS}

Table 2 shows the values of uPA:Ag in the blood plasma of patients operated on due to peritonitis. Distribution of uPA:Ag in the blood of the patients as well as the control 
TABLE 2. Pre-operative values of urokinase antigen of plasminogen activator in the blood plasma of patients with peritonitis and the control group

\begin{tabular}{|c|c|c|c|c|c|c|c|}
\hline \multirow{2}{*}{$\begin{array}{c}\text { The examined } \\
\text { parameter }\end{array}$} & \multicolumn{3}{|c|}{ Blood plasma of patients with peritonitis } & \multicolumn{3}{|c|}{ Blood plasma of control group } & \multirow{2}{*}{$\begin{array}{l}\text { Statistical } \\
\text { significance }\end{array}$} \\
\hline & n & $\mathrm{X}$ & SD & $\mathrm{n}$ & $\mathrm{X}$ & SD & \\
\hline uPA:Ag (ng/mL) & 60 & 0.3 & 0.05 & 25 & 0.5 & 0.1 & $p<0.016$ \\
\hline
\end{tabular}

$\mathrm{n}$ - number of patients; $\mathrm{X}$ - arithmetic mean; SD - standard deviation; $\mathrm{p}$ - statistical significance according to Student's t-test

TABLE 3. Comparison of urokinase antigen of plasminogen activator in the blood of patients with peritonitis before and after surgery

\begin{tabular}{|c|c|c|c|c|c|c|c|}
\hline \multirow{2}{*}{$\begin{array}{c}\text { The examined } \\
\text { parameter }\end{array}$} & \multicolumn{3}{|c|}{ Blood plasma of patients before operation } & \multicolumn{3}{|c|}{ Blood plasma of patients after operation } & \multirow{2}{*}{$\begin{array}{l}\text { Statistical } \\
\text { significance }\end{array}$} \\
\hline & n & $\mathrm{X}$ & SD & $n$ & $\mathrm{x}$ & SD & \\
\hline uPA:Ag (ng/mL) & 60 & 0.3 & 0.05 & 60 & 0.6 & 0.15 & $p<0.001$ \\
\hline
\end{tabular}

$\mathrm{n}$ - number of patients; $\mathrm{X}$ - arithmetic mean; SD - standard deviation; $\mathrm{p}$ - statistical significance according to Student's t-test

TABLE 4. Comparison of postoperative urokinase antigen of plasminogen activator values in the blood plasma with peritoneal fluid

\begin{tabular}{|c|c|c|c|c|c|c|c|c|c|}
\hline \multirow{2}{*}{$\begin{array}{c}\text { The examined } \\
\text { parameter }\end{array}$} & \multicolumn{4}{|c|}{ Blood plasma after operation } & \multicolumn{4}{|c|}{ Peritoneal fluid } & \multirow{2}{*}{$\begin{array}{l}\text { Statistical } \\
\text { significance }\end{array}$} \\
\hline & $\mathbf{n}$ & Me & IQ & III Q & $\mathrm{n}$ & Me & IQ & III Q & \\
\hline uPA:Ag (ng/mL) & 60 & 0.5 & 0.2 & 0.8 & 60 & 2.2 & 0.8 & 3.6 & $p<0.0001$ \\
\hline
\end{tabular}

$\mathrm{n}$ - number of patients; Me - median; I-Q - the 1st quartile; III-Q - the $3^{\text {rd }}$ quartile; $\mathrm{p}$ - statistical significance according to a Mann-Whitney U test

TABLE 5. Comparison of urokinase antigen of plasminogen activator concentration in the blood of patients with peritonitis and peritoneal fluid after conversion to gram protein

\begin{tabular}{|c|c|c|c|c|c|c|c|}
\hline \multirow{2}{*}{$\begin{array}{c}\text { The examined } \\
\text { parameter }\end{array}$} & \multicolumn{3}{|c|}{ Blood plasma } & \multicolumn{3}{|c|}{ Peritoneal fluid } & \multirow{2}{*}{$\begin{array}{l}\text { Statistical } \\
\text { significance }\end{array}$} \\
\hline & $\mathrm{n}$ & $\mathrm{x}$ & SD & $\mathrm{n}$ & $x$ & SD & \\
\hline Total protein (g/L) & 60 & 59.9 & 14.6 & 60 & 36.1 & 21.8 & $p<0.001$ \\
\hline uPA:Ag (ng/mL) & 60 & 0.07 & 0.01 & 60 & 0.7 & 0.015 & $p<0.001$ \\
\hline
\end{tabular}

$\mathrm{n}$ - number of patients; $\mathrm{X}$ - arithmetic mean; SD - standard deviation; $\mathrm{p}$ - statistical significance according to a Mann-Whitney U test

group showed features for normal distribution. The mean pre-operative concentration of uPA:Ag in the blood of patients was $0.3 \pm 0.05 \mathrm{ng} / \mathrm{mL}$ and was statistically significantly lower compared to the control group $(\mathrm{p}<0.016)$.

Table 3 compares pre-and post-operative concentrations of uPA:Ag in the blood of patients with peritonitis. Distribution of concentrations UPA:Ag after surgery showed features for normal distribution. After the operation there was a statistically significant increase in uPA:Ag $(\mathrm{p}<0.001)$.

Table 4 shows the comparison of uPA:Ag concentrations in peritoneal fluid and blood plasma of patients with peritonitis. The distribution of uPA:Ag in peritoneal fluid differed from a normal distribution $(\mathrm{p}<0.0001)$. To increase the strength of this comparison, the uPA concentration in blood plasma was also presented as a value of non-parametric analysis. The range of uPA concentrations in the peritoneal fluid was much wider than in the blood plasma. The $1^{\text {st }}$ and $3^{\text {rd }}$ quartiles were $0.8 \mathrm{ng} / \mathrm{mL}$ and $3.6 \mathrm{ng} / \mathrm{mL}$ respectively, while in the blood plasma $0.2 \mathrm{ng} / \mathrm{mL}$ and $0.8 \mathrm{ng} / \mathrm{mL}$. It is noteworthy that the median uPA:Ag in the blood $(0.5 \mathrm{ng} / \mathrm{mL})$ was significantly lower compared to the peritoneal fluid $(2.2 \mathrm{ng} / \mathrm{mL} ; \mathrm{p}<0.0001)$. In order to increase the objectivity of comparison of the peritoneal fluid with blood plasma, the concentration of uPA in each of them per gram of protein content was recounted. A normal distribution criteria after conversion to $1 \mathrm{~g}$ of protein was met only by blood plasma.
Table 5 compares the concentrations of uPA:Ag in the peritoneal fluid and in blood plasma after conversion to $1 \mathrm{~g}$ of protein. A similar tendency to their native concentrations was maintained. Definitely, the average concentration of uPA:Ag in the peritoneal fluid was much higher than in the blood plasma at $0.7 \pm 0.015 \mathrm{~g} / \mathrm{L}$ and $0.07 \pm 0.01 \mathrm{~g} / \mathrm{L}$ respectively (statistically significant difference $\mathrm{p}<0.001$ ).

Analysis of the correlation between uPA concentrations in the blood plasma and peritoneal fluid allowed us to reject the hypothesis of the existence of a relationship between these concentrations at a level of statistical significance $\mathrm{p}<0.03$. The calculated Spearman rank factor $r=0.2$ (Fig. 1).

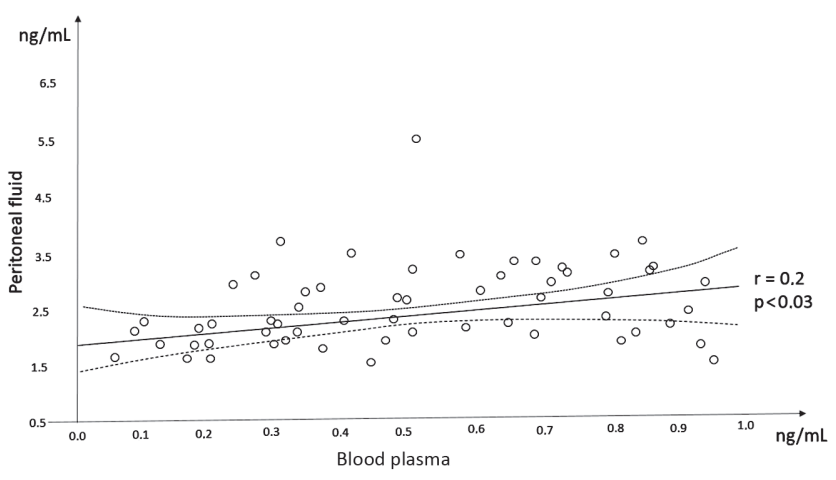

FIGURE 1. The correlation of UPA concentration in peritoneal fluid and in plasma of patients with peritonitis 
The increase in post-operative uPA:Ag in the blood plasma of patients with peritonitis proves intravascular activation of fibrinolysis. The presence of uPA in peritoneal fluid indicates intraperitoneal activation of fibrinolysis. The lack of a clear relationship between the uPA concentration in blood plasma and its concentration in the peritoneal fluid may indicate, with high probability, a variety of sources of uPA. Undoubtedly, the sources of plasma uPA are primarily endothelial cells and other morphotic blood elements, while the sources of peritoneal uPA:Ag are undecided. In the light of other reports, peritoneal mesothelial cells are indicated as a main source [16]. It is believed that mesothelial cells change phenotype in response to injury and returns to normal only after tissue repair [16]. This mesothelial change might be an active form that participates through the complete inflammatory process, including tissue repair [17]. Additionally, mesothelial cells have demonstrated the ability to participate in fibrinolytic, procoagulant and fibrinogenic activity $[6,7,8]$.

In the light of our own results and contrary to common opinion, it can be concluded that peritonitis does not inhibit intraperitoneal fibrinolytic activity. The existence of intraperitoneal fibrinolysis has been confirmed in observations by Tarhan et al., however, the authors showed the presence of another plasminogen activator, t-PA [11]. Similarly to our analysis of peritoneal fluid, Brokelman et al. also showed the presence of $\mathrm{UPA}$, concluding that there is no place for a further hypothesis of inhibition of intraperitoneal fibrinolysis during peritonitis [18]. Reports by van Goor et al. also confirm the presence of uPA in peritoneal fluid. As in our observations, they did not show any correlation of UPA concentration between peritoneal fluid and blood plasma [19].

Another intriguing idea regarding intra-peritoneal fibrinolysis was adopted by Dörr et al. [14]. Although the authors found 2 types of plasminogen activators ( $\mathrm{UPA}$ and t-PA) and signs of fibrinolytic activity, its effectiveness in the prevention of adhesions was due to many factors affecting the balance between fibrinolysis and coagulation. They came to the conclusion that if the balance moves towards coagulation, intraperitoneal fibrinolysis may be insufficient to dissolve the adhesions. We strongly support and agree with this. Since the activated fibrinolysis does not meet the demand, there is a field for therapeutic intervention to prevent adhesions [14].

The above suggestions have already been applied in clinical practice. A group of authors under the leadership of Buyne showed that the therapy of plasminogen activators such as t-PA and $\mathrm{UPA}$ in peritonitis reduced the number of postoperative abscesses and adhesions [20].

However, there are still reports highlighting the inhibition of fibrinolysis in peritonitis. Such studies have been carried out by many research centers, by among others Neudecker et al. The authors showed a decrease in intraperitoneal concentration of t-PA, followed by the inhibition of fibrinolytic activity. According to the authors, this all only confirms that the problem of intraperitoneal fibrinolysis is not a closed chapter $[12,13]$.
It should be emphasized once again that the formation of postoperative adhesions and intra-abdominal abscesses may be determined not only by fibrinolytic activity but by many other factors yet unknown. These factors affect the intra-abdominal balance between coagulation and fibrinolysis. So the efficacy of dissolving intraperitoneal fibrin deposits is the result of a violation of this delicate balance. These observations confirm the results of the works by Dörr et al. and Hellebrekers et al. $[14,21]$.

\section{CONCLUSIONS}

Prospective studies in humans may add further weight to the common hypothesis of the impact of peritonitis on peritoneal fibrinolytic activity. The activation of fibrinolytic process or adhesion formation is not a simple pathway and requires further study. Focusing on this, it seems that uPA could be a potential marker for intraperitoneal fibrinolytic activity and be helpful in the identification of patients with a low risk of developing adhesions. Applying uPA in intra-abdominal fibrinolytic therapy after an operation is the next worthy issue.

\section{REFERENCES}

1. Isaza-Restrepo A, Martin-Saavedra JS, Velez-Leal JL, Vargas-Barato F, Riveros-Dueñas R. The peritoneum: beyond the tissue - a review. Front Physiol 2018;9:738. doi: 10.3389/fphys.2018.00738.

2. Herrick SE, Mutsaers SE. Mesothelial progenitor cells and their potential in tissue engineering. Int J Biochem Cell Biol 2004;36:621-42.

3. van Baal JO, Van de Vijver KK, Nieuwland R, van Noorden CJF, van Driel WJ, Sturk A, et al. Review: the histophysiology and pathophysiology of the peritoneum. Tissue Cell 2017;49(1):95-105.

4. Burn SF, Hill RE. Left-right asymmetry in gut development: what happens next? Bioessays 2009;31(10):1026-37. doi: 10.1002/bies.200900056.

5. Susan Y, Tak Mao C. Pathophysiological changes to the peritoneal membrane during PD-related peritonitis: the role of mesothelial cells. Med Inflamm 2012:484167. doi: 10.1155/2012/484167.

6. van Hinsbergh VWM, Kooistra T, Scheffer MA, Van Bockel JH, Van Muijen GNP. Characterization and fibrinolytic properties of human omental tissue mesothelial cells. Comparison with endothelial cells. Blood 1990;75(7):1490-97.

7. Pronk A, De Groot PG, Hoynck van Papendrecht AA, Verbrugh HA, Leguit $P$, Van Vroonhoven TJ, et al. Thrombogenicity and procoagulant activity of human mesothelial cells. Arterioscler Thromb 1992;12(12):1428-36. doi: 10.1161/01.ATV.12.12.1428.

8. Davies SJ, Yewdall VMA, Ogg CS, Cameron JS. Peritoneal defence mechanisms and Staphylococcus aureus in patients treated with continuous ambulatory peritoneal dialysis (CAPD). Perit Dial Int 1990;10(2): 135-40.

9. Zorio E, Gilabert-Estellés J, España F, Ramón LA, Cosín R, Estellés A. Fibrinolysis: the key to new pathogenetic mechanisms. Curr Med Chem 2008;15:923-9.

10. Matthews RD, Neumayer L. Inguinal Hernia in the 21st Century: an evidence-based review. Curr Probl Surg 2008;45(4):261-312. doi: 10.1067/j. cpsurg.2008.01.002.

11. Tarhan OR, Barut I, Akdeniz Y, Sutcu R, Cerci C, Bulbul M. Fibrinolytic responses of human peritoneal fluid in laparoscopic cholecystectomy: a prospective clinical study. Surg Endosc 2008;22:1008-13.

12. Neudecker J, Junghans T, Raue W, Ziemer S, Schwenk W. Fibrinolytic capacity in peritoneal fluid after laparoscopic and conventional colorectal resection: data from a randomized controlled trial. Langenbecks Arch Surg 2005;390:523-7. 
13. Neudecker J, Junghans T, Ziemer S, Raue W, Schwenk W. Effect of laparoscopic and conventional colorectal resection on peritoneal fibrinolytic capacity: a prospective randomized clinical trial. Int J Colorectal Dis 2002;17:426-9.

14. Dörr PJ, Brommer EJ, Dooijewaard G, Vemer HM. Peritoneal fluid and plasma fibrinolytic activity in women with pelvic inflammatory disease. Thromb Haemost 1992;68(2):102-5.

15. Lobov S, Ranson M. Molecular competition between plasminogen activator inhibitors type -1 and -2 for urokinase: implications for cellular proteolysis and adhesion in cancer. Cancer Lett 2011;303:118-27.

16. Saed G, Kruger M, Diamond M. Enhanced matrix metalloproteinase expression by Tisseel in mesothelial cells, normal peritoneal fibroblasts, and adhesion fibroblasts. Eur Plast Surg 2006;28:472-9. doi: 10.1007/s00238-005-0006-1.

17. Mutsaers SE. Cells in focus: the mesothelial cell. Int J Biochem Cell Biol 2004;36:9-16. doi: 10.1016/S1357-2725(03)00242-5.
18. Brokelman WJ, Holmdahl L, Bergström M, Falk P, Klinkenbijl JH, Reijnen MM. Peritoneal fibrinolytic response to various aspects of laparoscopic surgery: a randomized trial. J Surg Res 2006;136:309-13.

19. van Goor H, Bom VJ, van der Meer J, Sluiter WJ, Bleichrodt RP. Coagulation and fibrinolytic responses of human peritoneal fluid and plasma to bacterial peritonitis. Br J Surg 1996;83:1133-5.

20. Buyne OR, van Goor H, Bleichrodt RP, Verweij PE, Hendriks T. Both tissue-type plasminogen activator and urokinase prevent intraabdominal abscess formation after surgical treatment of peritonitis in the rat. Surgery 2008;144:66-73. doi: 10.1016/j.surg.2008.03.025.

21. Hellebrekers BW, Emeis JJ, Kooistra T, Trimbos JB, Moore NR, Zwinderman $\mathrm{KH}$, et al. A role for the fibrinolytic system in postsurgical adhesion formation. Fertil Steril 2005;83:122-9. 